\title{
Biological Decline of Solanum nigrum L. Due to Tobacco Mosaic Tobamovirus (TMV) Infection I. Growth and Nutrient Uptake*
}

\author{
G. KAZINCZI, D. PRIBÉK and A. TAKÁCS \\ Department of Plant Pathology and Plant Virology, Institute for Plant Protection, \\ University of Veszprém, Georgikon Faculty of Agricultural Sciences, \\ H-8361 Keszthely, P.O. Box 71, Hungary
}

\begin{abstract}
The aim of our study was to examine the effect of tobacco mosaic tobamovirus (TMV) infection on the growth and nutrient content of $S$. nigrum leaves. TMV infection significantly reduced the height, the fresh and dry weight of both the shoots and roots. The height of the shoots was reduced by $53 \%$ as compared to control. Reduction in fresh and dry weight of shoots and roots due to virus infection varied between 78 and $82 \%$. There was no significant difference in the nitrogen $(\mathrm{N})$, phosphorus $(\mathrm{P})$ and calcium $(\mathrm{Ca})$ content of the healthy and virus infected leaves of $S$. nigrum. The sodium $(\mathrm{Na})$, magnesium $(\mathrm{Mg})$, iron $(\mathrm{Fe})$, manganese $(\mathrm{Mn})$, zinc $(\mathrm{Zn})$ and copper $(\mathrm{Cu})$ content of the leaves significantly reduced due to virus infection. Opposite effect was observed in case of potassium $(\mathrm{K})$ content, which were considerably enhanced in the TMV infected leaves.
\end{abstract}

Keywords: Solanum nigrum, TMV, tobacco mosaic tobamovirus.

Weeds can influence the quality and quantity of crops not only in a direct way (e.g. by competing for nutrient and water uptake), but also as alternative hosts of various pathogens. Alternative hosts serve as food for the vectors of viruses, while the seeds and vegetative reproductive organs of certain weed species play an important role in the epidemiology and overwintering of viruses. The positive side of the indirect effect is the so-called "bioherbicide strategy", when natural enemies of weeds (pests, pathogens) are used for suppression of a weed population. Biological decline of weeds due to virus infection have been recently studied. It was stated that germination and seed viability of Chenopodium seeds from the sowbane mosaic sobemovirus (SoMV) infected plants was strongly reduced, therefore virus infection may contribute indirectly to the reduction of weed seed bank of the soil (Kazinczi et al., 1997, 2000; Kazinczi and Horváth, 1998a). Both cucumber mosaic cucumovirus (CMV) and henbane mosaic potyvirus (HeMV) retarded the growth of Datura stramonium. Besides this, the disturbance of water relation of D. stramonium and S. nigrum was observed due to HeMV and CMV infection, respectively. Additionally, CMV infection significantly reduced the photosynthetic pigment content of Datura stramonium leaves (Kazinczi et al., 1996, 1998c).

A lot of study have dealt with the effect of different nutrients on the development of pathogens and disease symptoms on crops. The effect of different nutrients on the occurrence of disease symptoms and development of the pathogens may vary greatly, depending on the type and dosage of fertilizers, the ratio of the different elements, host plant and pathogen species and the phase of the development of the pathogens (Standaert et al., 
1978; Shaikh and Ghaffar, 1986; Cloud and Rupe, 1994; Reuveni et al., 1995). Viral infection may result in an increase of the exudation of nutrients from roots of infected hosts, which may enhance the potentiality of root fungal pathogens of those hosts (Beute and Lockwood, 1968). In spite the fact that a lot of study have dealt with the effect of nutrients on the development of the pathogens and plant disease, little data is available about the changing of the nutrient content of the host plants due to the different pathogens. Kazinczi et al. (1998a, b) studied the effect of Macrophomina phaseolina and viruses on the nutrient content of pepper leaves. It was concluded that the infections have played an important role in the early nutrient uptake of pepper and after flowering no significant reduction was observed. In case of several mixed infection with viruses and fungus the reduction in the nutrient content of the pepper leaves was greater. Although the nutrient content of the weeds was intensively studied by different authors (Tölgyesi, 1969; Debreczeni, 1988; Lehoczky, 1988; Kazinczi, 1993; Lukács et al., 1998) comparative investigations have not yet been available, regarding the healthy and virus infected plants.

Members of the family Solanaceae have economical and also virological importance. $S$. nigrum is reported as a weed in 37 crops and in 73 countries (Holm et al., 1977). In Hungary, under moist environments and high fertility of soils in late-sown cultures especially in vegetables - it is considered to be a noxious weed (Hunyadi et al., 1998). It is tolerant to the dinitroaniline type herbicides (Kádár, 1983), which are frequently used in vegetable and triazine resistant biotype of $S$. nigrum is also known (Garcia-Baudin and Aguirre, 1983). S. nigrum is known as a virophilous species and host of 43 viruses (Mariappan et al., 1973; Davis and Allen, 1975; Schmelzer and Wolf, 1977; Wilson et al., 1981; Dimitrievič, 1985; Alegbejo, 1987; Farrel and Stufkens, 1988; Daniel and Tsai, 1990; Kazinczi and Horváth, 1998b). It is natural hosts of Polymyxa betae fungi, which is the main vector of a serious sugarbeet virus, beet necrotic yellow vein benyvirus (Vurbanov and Kroumov, 1989). Kistah et al. (1986) studied physiological and ultrastructural changes of S. nigrum due to potato Y potyvirus (PVY) infection. On the basis of their observation the chlorophyll content of the leaves decreased, respiration rate increased and ultrastructural changes of mitochondrium, chloroplast and cell wall were also observed.

The aim of our study was to examine the effect of TMV infection on the growth and nutrient content of $S$. nigrum leaves.

\section{Materials and Methods}

Seeds of $S$. nigrum were sown in sterilized boxes in the virological glasshouse free of vectors. The seedlings were planted in plastic pots $(28 \mathrm{~cm}$ in diameter), containing a soil mixture of sand (pH: 6.96, humus\%: 0.27): peat (pH: 6.78, humus \%: 9.98) 1:3. S. nigrum plants were mechanically inoculated at 6-8 leaf stage with U1 strain of tobacco mosaic tobamovirus (TMV/U1). Previously the virus was propagated on Nicotiana tabacum L. cv. Samsun. There were four plants in a pot and eight replicates of control and TMV infected plants. Tests continued for 90 days, when the fresh and dry weight both of the shoots and roots of plants were measured. To determine the nutrient content, leaf samples were collected at flowering (at the end of July). The nitrogen $(\mathrm{N})$, phosphorus 
$(\mathrm{P})$, potassium $(\mathrm{K})$ and sodium $(\mathrm{Na})$ content was determined after destruction with sulphuric acid by a photometer. $\mathrm{K}$ and $\mathrm{Na}$ content was determined by flame photometer. After hydrochloric hydrolysis, atomadsorption spectrophotometer was used to determine the calcium $(\mathrm{Ca})$, magnesium $(\mathrm{Mg})$, zinc $(\mathrm{Zn})$, copper $(\mathrm{Cu})$, manganese $(\mathrm{Mn})$ and iron (Fe) content of the leaves.

\section{Results and Discussion}

TMV infection significantly reduced the height, the fresh and dry weight of both the shoots and roots. The height of the shoots was reduced by $53 \%$ as compared to control. Reduction in fresh and dry weight of shoots and roots due to virus infection varied between 78 and $82 \%$ (Table 1).

Table 1

The effect of tobacco mosaic tobamovirus (TMV) infection on the growth of Solanum nigrum L.

\begin{tabular}{lccccc}
\hline & \multirow{2}{*}{ Height $(\mathrm{cm})$} & \multicolumn{2}{c}{ Fresh weight $(\mathrm{g})$} & \multicolumn{2}{c}{ Dry weight $(\mathrm{g})$} \\
& & Shoot & Root & \multicolumn{1}{c}{ Shoot } & \multicolumn{1}{c}{ Root } \\
\hline Control & $88(4)^{*}$ & $43.2(1.7)$ & $5.5(1)$ & $4.2(0.9)$ & $0.58(0.19)$ \\
TMV & $41(7)$ & $9.5(4.6)$ & $0.98(0.3)$ & $0.88(0.60)$ & $0.13(0.10)$ \\
LSD $5 \%$ & 3.32 & 3.66 & 0.78 & 1.44 & 0.25 \\
\hline
\end{tabular}

*numbers in brackets indicate the standard error

There was no significant difference in the nitrogen $(\mathrm{N})$, phosphorus $(\mathrm{P})$ and calcium $(\mathrm{Ca})$ content of the healthy and virus infected leaves of $S$. nigrum. The sodium $(\mathrm{Na})$, magnesium $(\mathrm{Mg})$, iron $(\mathrm{Fe})$, manganese $(\mathrm{Mn})$, zinc $(\mathrm{Zn})$ and copper $(\mathrm{Cu})$ content of the leaves significantly reduced due to virus infection. Opposite effect was observed in case of potassium $(\mathrm{K})$ content, which were considerably enhanced in the TMV infected leaves (Figs 1, 2). The physiological and biochemical background of this unexpected observation is not yet clear. In a previous experiment viruses alone did not decrease considerably the $\mathrm{K}$ content of pepper leaves, while significant reduction of $\mathrm{K}$ content was observed due to complex infection of M. phaseolina and viruses (Kazinczi et al., 1998b).

Our results underpin the previous statement that viruses unfavourably influence physiological processes of the weeds therefore - in indirect way - viruses may contribute to the reduction of their competitive ability. Previously we have proved that CMV infection reduced the drought resistance of $S$. nigrum as compared to the healthy ones (Kazinczi et al., 1998c). Considering that formerly the physiological examinations of the virus diseased plants were connected mainly with the cultivated plants, therefore our present work supplies new data to the biological decline of the virus diseased weed plants. 


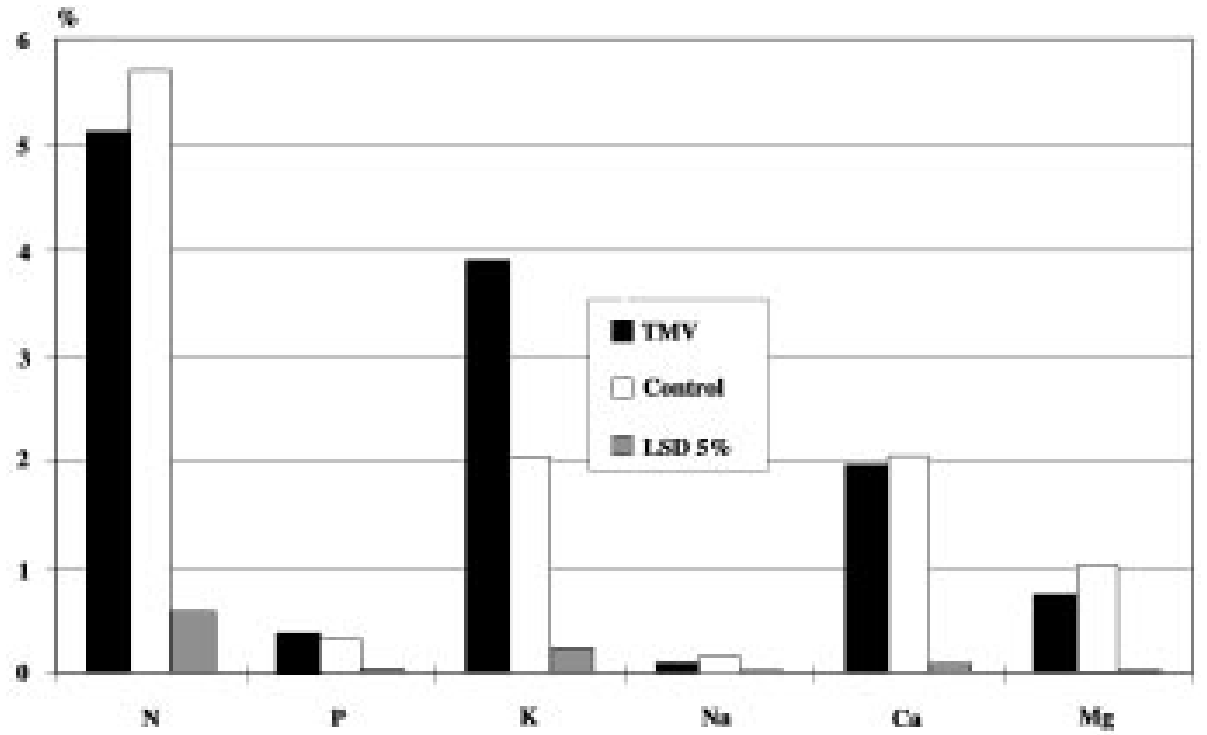

Fig. 1. The effect TMV infection on the nitrogen $(\mathrm{N})$, phosphorus $(\mathrm{P})$, potassium $(\mathrm{K})$, sodium $(\mathrm{Na})$, calcium $(\mathrm{Ca})$ and magnesium $(\mathrm{Mg})$ content of Solanum nigrum leaves

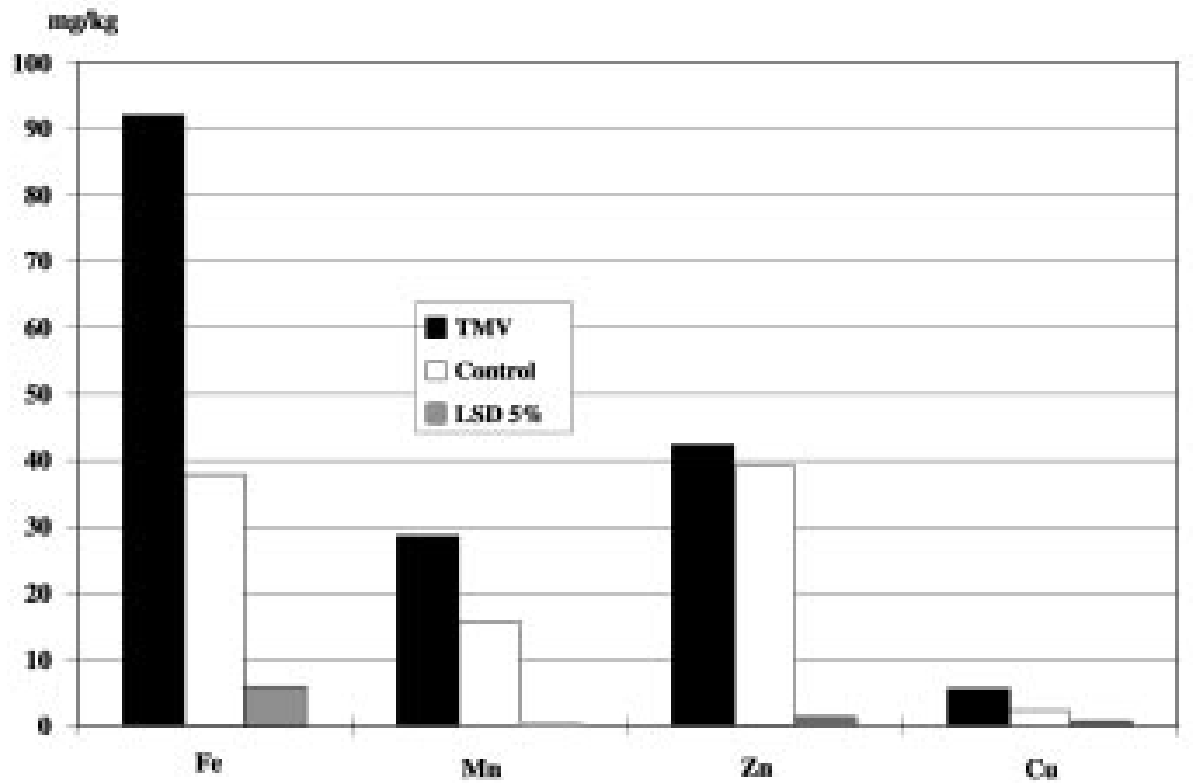

Fig. 2. The effect of TMV infection on the iron (Fe), manganese $(\mathrm{Mn})$, zinc $(\mathrm{Zn})$ and copper $(\mathrm{Cu})$ content of Solanum Nigrum leaves 


\section{Literature}

Alegbejo, M. D. (1987): Identification of a weed host of pepper veinal mottle virus in northern Nigeria. Samaru J. Agric. Res. 5, 65-70.

Beute, M. K. and Lockwood, J. L. (1968): Mechanisms of increased root rot in virus infected peas. Phytopathology $58,1643-1651$.

Cloud, G. L. and Rupe, J. C. (1994): Influence of nitrogen, plant growth stage and environment on charcoal rot grain sorghum caused by Macrophomina phaseolina (Tassi) Goid. Plant and Soil 158, 203-210.

Daniel, L. L. and Tsai, J. H. (1990): Partial characterization and serological analysis of pseudo curly top virus. Plant Dis. 74, 17-21.

Davis, J. R. and Allen, T. G. (1975): Weed hosts of the tobacco rattle virus in Idaho. Amer. Potato J. 52, 1-8.

Debreczeni, K. (1988): A gyomnövények kémiai összetétele. In: Hunyadi, K. (szerk.), Szántóföldi gyomnövények és biológiájuk (Chemical Components of Weeds. In: Hunyadi, K. (ed.), The Biology of Arable Weeds). Mezőgazdasági Kiadó, Budapest 1988. pp. 314-341.

Dimitrievič, B. (1985): Reaction of host plants to grapevine Bulgarian latent virus in mixed infections with other viruses from grapevine. Phytopathol. Medit. 24, 12-14.

Farrel, J. A. and Stufkens, M. V. (1988): Flight activity and weed hosts of Macrosiphini (Homoptera: Aphididae) in Canterbury. J. Exp. Agric. (New Zealand) 16, 209-218.

Garcia-Baudin, J. M. and Aguirre, R. (1983): Comparacion de la germinacion de un biotipo sensible Y otroresistente a la atrazina, de Solanum nigrum ssp. nigrum. Anales del Instituto Nacional de Investigaciones Agrarias. Agricola 23, 71-78.

Holm, L. G., Plucknett, D. L., Pancho, J. V. and Herberger, J. P. (1977): The World's Worst Weeds. Univ. Hawaii Press, Honolulu 1977. 609 pp.

Hunyadi, K., Kazinczi, G. and Berzsenyi, Z. (1998): Fekete csucsor (Solanum nigrum). In: Csibor, I., Hartmann, F., Princzinger, G. and Radvány, B. (eds), Veszélyes 24. A leggyakoribb gyomnövények és az ellenük való védekezés (Black nightshade (Solanum nigrum). In: Csibor, I., Hartmann, F., Princzinger, G. and Radvány, B. (eds), Serious 24. Common Weeds in Hungary and Protection Against Them. Mezőföldi Agrofórum Kft, Szekszárd 1998. pp. 38-44.

Kádár, A. (1983): Gyomirtás, vegyszeres termésszabályozás (Weed Control, Chemical Yield Regulators). Mezőgazdasági Kiadó, Budapest 1983. 1-520 pp.

Kazinczi G. (1993): Őszi búzában károsító gyomnövények biológiája (Weed biology of winter weeds). PhD thesis, Keszthely 1983. 1-116 pp.

Kazinczi, G. and Horváth, J. (1998a): Transmission of sowbane mosaic sobemovirus by seeds of Chenopodium species and viability of seeds. Acta Phytopath. et Entomol. 33, 21-26.

Kazinczi, G. and Horváth, J. (1998b): Solanum nigrum L. as a new experimental host of Melandrium yellow fleck bromovirus and sowbane mosaic sobemovirus. Acta Phytopath. et Entomol. 33, 27-30.

Kazinczi, G., Horváth, J., Hunyadi, K. and Merkel, K. (1997): Effect of sowbane mosaic sobemovirus (SoMV) on the germination biology of some Chenopodium species. Acta Phytopath. et Entomol. 32, 117-123.

Kazinczi, G., Kadlicskó, S. and Horváth, J. (1998a): The effect of Macrophomina phaseolina (Tassi) Goid. and two viruses on pepper (Capsicum annuum L.). Acta Phytopath. et Entomol. 33, 61-68.

Kazinczi, G., Horváth, J. and Kadlicskó, S. (1998b): The effect of Macrophomina phaseolina (Tassi) Goid. and two viruses on the nutrient content of pepper (Capsicum annuum L.) leaves. Acta Phytopath. et Entomol. 33, 305-311.

Kazinczi, G., Horváth, J. and Hunyadi, K. (1998c): Sublethal water saturation deficit of the healthy and virus infected black nightshade (Solanum nigrum L.). Acta Phytopath. et Entomol. 33, 237-242.

Kazinczi, G., Horváth, J. and Lukács, D. (2000): Germination characteristics of Chenopodium seeds derived from healthy and virus infected plants. Z. PflKrankh. PflSchutz, Sonderh. XVII, 63-67.

Kazinczi, G., Horváth, J. and Pogány M. (1996): The effect of virus infection on the growth and photosynthetic pigment content of the virophilous Jimson weed (Datura stramonium L.). Acta Phytopath. et Entomol. $31,175-179$. 
Kistah, A. A., Eskaroous, J. K., Habib, H. M. and Ismah, M. H. (1986): Effect of potato virus Y on the ultrastructure and some physiological processes of Solanum nigrum. Egyptian J. Phytopathol. 15, 65-76.

Lehoczky, É. (1988): Fontosabb egyéves és évelő gyomnövények tápanyagfelvétele (Nutrient uptake of some annual and perennial weeds). $\mathrm{PhD}$ thesis, Keszthely, 1988.

Lukács, D., Hunyadi, K. and Kazinczi, G. (1998): Studies on the bud activity and nutrients uptake of reed (Phragmites australis (Cav.) Trin ex Steudel). Z. Pflkrankh. PflSchutz, Sonderh. XVI, 217-221.

Mariappan, V., Govidaswamy, C. V. and Ramakrishnan, K. (1973): Studies on the role of weed plants in the spread of virus diseases. 2. Role of Solanum nigrum chilli mosaic virus, a strain of potato virus Y. Madras Agric. J. 60, 120-121.

Reuveni, M., Agapov, V. and Reuveni, R. (1995): Suppression of cucumber powdery mildew (Sphaerotheca fuliginea) by foliar sprays of phosphate and potassium salts. Plant Pathology 44, 31-39.

Schmelzer, K. and Wolf, P. (1977): Wirtspflanzen und ihre Viren, Virosen und Mykoplasmosen. In: Klinkowski, M. (ed.), Pflanzliche Virologie. Registerband Verzeichnisse und Übersichten zu den Virosen in Europa. Akademie Verlag, Berlin 1977. pp. 53-189.

Shaikh, A. H. and Ghaffar, A. (1986): Reduction of sclerotial numbers of Macrophomina phaseolina in soil. Nfertilizers. Tehnique 4, 51-58.

Standaert, J. Y., Maraite, H., Myttenaere, C. and Meyer, J. A. (1978): Étude de l'influence de la concentration saline et du rapport sodium/calcium du milieu nutritif sur la sensibilité de la tomate a la fusariose vasculaire. Plant and Soil 50, 269-286.

Tölgyesi, Gy. (1969): A növények mikroelemtartalma és ennek mezőgazdasági vonatkozásai (Microelements of Plants and Relation with Agricultural Practice). Mezőgazdasági Kiadó, Budapest 1969.

Vurbanov, V. and Kroumov, K. (1989): Spread and the hosts of Polymyxa betae, parasite of sugarbeet and vector of rhizomania pathogen. Rasteniev dni Nauki 26, 80-85.

Wilson, K. I., Al-Beldawi, A. S., Amin, M. and Nema, H. A. (1981): Solanum nigrum, a new host of tomato yellow leaf curl virus. Plant Dis. 65, 979. 